\title{
Av og til helbrede, ofte lindre, men alltid trøste?
}

Sykepleiere må aldri slutte å stille spørsmål ved hva slags praksis de arbeider i. Når debattene kommer, er det et sunnhetstegn for sykepleieprofesjonen, skriver Elisabeth Sveen Kjølsrud.

\section{Elisabeth Sveen Kjølsrud}

Leder

Rådet for sykepleieetikk

Sykepleien 2016104 (10) (44 45)

DOI: 10.4220/Sykepleiens.2016.59278

Er ensomhet helsevesenets oppgave? Dette spørsmålet ble stilt i forbindelse med en sak på oktobermøtet til Rådet for sykepleieetikk. Utgangspunktet for saken var at en helsearbeider i hjemmetjenesten skrev et leserinnlegg i lokalavisen og fortalte at hun hadde dårlig samvittighet på hver eneste vakt. Hun etterlyste mindre tidspress og mer tid til å være medmenneske.

Saken vakte stor interesse og satte sinnene i kok, ikke minst da en tjenesteleder valgte å svare offentlig på innlegget til helsearbeideren. Mange kastet seg på debatten. Støtten gikk begge veier.

\section{Tjenestelederen skrev:}


«Helsepersonell som klager over evig dårlig samvittighet på jobb, må heller endre sine egne holdninger og jobbe annerledes i tråd med kontinuerlig utvikling og organisering av driften $i$ avdelingene. Da vil de oppleve å få bedre tid. For det er ikke alltid systemet vi kan skylde på når vi har dårlig tid. Det er viktig at man er villig til å følge utviklingen og endrete driftsrutiner.»

Tjenestelederen understreker videre at eldres ensomhet ikke er hjemmetjenestens ansvar, og at sosial st $\varnothing$ ttefunksjon ikke omtales i lovverket. Hun er imidlertid usikker på hvor ansvaret skal plasseres. Hun viser videre til at «glansdagene» $\mathrm{i}$ hjemmetjenesten er over.

\section{Saken er viktig og prinsipiell}

Rådet for sykepleieetikk forstår godt tjenestelederens dilemma. Ledere skal ta flere hensyn og har krevende oppgaver. De skal lytte til medarbeiderne samtidig som de skal forholde seg til politiske krav og organisasjonens budsjetter. Vi berømmer samtidig helsearbeideren som tok opp denne viktige saken til debatt. Rådet synes saken er viktig og av prinsipiell betydning, og den reiser mange spørsmål og dilemmaer.

Debatten er heller ikke enestående. Rådet mottar med jevne mellomrom bekymringsmeldinger om tidsklemme og stoppeklokkeomsorg. Moralsk stress er blitt et kjent begrep, noe også omfattende forskning viser, ikke bare her til lands, men også fra andre vestlige land (Austin, W. 2012, Lutzen, K. mfl. 2002, Lützen, K., Kvist, B.E., Clancy, A. og Kjølsrud, E. 2013).

Moralsk stress er ikke et nytt fenomen. Likevel har forskning vist at det er grunn til å tro at det moralske stresset har $\varnothing \mathrm{kt}$. En grunn til dette er at nye styringsideologier, markedstenkning og profesjonsnøytralitet har preget helsevesenet de siste tiårene, hvor nettopp tidspress og effektivitet har vært sentralt. Vi vet at også demografiske forhold spiller inn. Saken er kompleks. 


\section{Moralen sitter i kroppen}

Hallvard Vike (2002) beskriver sykepleieres dilemma på en slående måte: «Det er sykepleieren som bærer organisasjonens grenser i kroppen. På den måten opplever sykepleierne et identitetsproblem samtidig som de får et lojalitetsproblem.»

Det er med andre ord ofte sykepleieren som tar på seg ansvaret for at kommuner og sykehus skal vise et menneskelig ansikt utad. Sykepleierne er også tradisjonelt garantister for kvalitet, men lever samtidig daglig med uforenlige krav. De sitter igjen med moralsk stress. De nye styringsideologiene representerer en rasjonalistisk tankegang der man tar høyde for at endrete holdninger er det som skal til. Den tankegangen er ikke tilstrekkelig for å forstå kompleksiteten i saken. Helsearbeideren som gikk til media, forteller en helt annen historie. Moralen sitter i kroppen. Det betyr at sykepleiere ikke bare er rasjonelle aktører.

Saken har mange involverte parter: pasienten, pleierne, arbeidsgiveren, pårørende, samfunnet og politikerne. Med andre ord gjelder denne saken oss alle.

\section{God sykepleie}

Utsagnet «Av og til helbrede, ofte lindre, men alltid trøste» er viktige idealer for alle helsearbeidere. I yrkesetiske retningslinjer, punkt 2, omtales sykepleieren og pasienten: «Sykepleieren ivaretar den enkelte pasients verdighet og integritet, herunder retten til faglig forsvarlig og omsorgsfull hjelp, retten til å være medbestemmende og retten til ikke å bli krenket.» 
Videre i punkt 2.1 står det: «Sykepleieren har ansvar for en sykepleiepraksis som fremmer helse og forebygger sykdom.» Sykepleie handler om mellommenneskelig kontakt, ansikt til ansikt. God sykepleie handler om å styrke pasienters evne til mestring og om å gi trygghet, verdighet og respekt. Sykepleie handler om å ivareta hele mennesket. Sykepleie handler også om å forebygge lidelse i samarbeid med pasient og pårørende. Dette er viktig da vi vet at ensomhet blant annet kan føre til depresjon.

Ensomhet kan også føre til alvorlige somatiske lidelser. Pasientene kan bli dehydrerte og miste matlysten, noe som kan føre til forvirring og fall. Tid er og blir dermed en avgjørende faktor.

Rådet for sykepleieetikk mener at det er viktige sykepleieverdier som står på spill. Samtidig vet vi at oppgavene sykepleierne står overfor, kan synes grenseløse. En avgrensning er nødvendig. Ensomhet i vår tid er ikke sykepleiernes ansvar alene. Ansvaret bærer vi alle, og ikke minst politikerne som legger premissene.

\section{Tid til refleksjon}

Moralsk stress er alvorlig og har mange konsekvenser for både sykepleierne og pasientene. Det ødelegger arbeidsglede og kan føre til sykefravær. Vi vet også at mange sykepleiere $\varnothing$ nsker seg bort fra hjemmetjenesten og sykehjem. Vi vet at pasientene til alt overmål kan begynne å ta ansvar for sykepleiernes ve og vel når de ser at sykepleierne har lite tid og er stressete. Forskning har vist at noen pasienter skammer seg over hjelpebehovet de har. Det blir en ond sirkel.

Rådet for sykepleieetikk vet at refleksjon rundt praksis er med på å redusere moralsk stress. Derfor anbefaler vi at det settes av regelmessig tid til refleksjon på alle arbeidsplasser. 
Refleksjon er ikke diskusjon. Refleksjon handler om

det å se saken på nytt, om bevisstgjøring og ettertanke.

Sammen med kolleger lytter vi til hva den andre sier, hvordan det oppleves og hvordan vi skal håndtere både sak og følelser.

Til refleksjon: Hvordan håndterer dere moralsk stress

på arbeidsplassen? 